\title{
Emergency Room Visits for Suicide Attempts: Rates, Trends and Sociodemographic Characteristics of Suicide Attempts in Northeastern Anatolia
}

\author{
Murat Eroglu' , Ali Osman Yildirim', Mustafa Uzkeser², Ayhan Saritas², Hamit Acemoglu³, \\ Murat Navruz ${ }^{4}$, Mucahit Emet ${ }^{2}$
}

\section{ÖZET:}

Intihar girişimleri nedeniyle acil servis başvuruları: Kuzeydoğu Anadolu'da intihar girişimlerinin hızları, eğilimleri ve sosyodemografik özellikleri

Amaç: Bu çalışmada biz intihar girişimlerinin epidemiyolojisini özellikle intihar girişim hızlarına ve eğilimlerine odaklanarak değerlendirmeyi amaçladık.

Gereç ve Yöntemler: Bu çalışma üç yıllık bir süre içerisinde iki komşu ildeki 17 devlet hastanesinin acil servislerinde kaydedilen 893 intihar girişimi olayını içeren bir prospektif kesitsel çalışmadır. Her bir vakaya ait bilgiler kaydedildi ve psikososyal ve sosyodemografik özelliklerin bir serisini içeren standardize gözlem formuna kodlandı.

Bulgular: 2007 yılı verilerine göre ortalama intihar girişim hızı 100,000 kişide, kadınlar için 47,7, erkekler için 17,7 ve her iki cinsiyet birlikte ele alındığında 32,5 idi. 50 yaş üzeri yaş grubu hariç tüm gruplarda, kadınlarda intihar girişimi sayısı erkeklerden fazlaydı. En yaygın kasıtlı kendine zarar verme tipleri şu şekildedir: tıbbi ilaçlarıntoksik maddenin alımı $(\% 93,3)$, asma $(\% 1,7)$, kesme veya saplama $(\% 3,6)$. Ev hanımları $(\% 53,8)$, kadınlar arasında en geniş grubu oluşturdu. Aile içi fiziksel şiddet 15-34 yaş aralığında olan ve intihar girişiminde bulunan kadınlar arasında yaygın bir nedendi. Maddi sıkıntılar ise sadece erkeklerin baskın olarak görüldüğü intihar girişimi nedenlerindendi. Daha önceki psikiyatrik tanılar parasuisid vakaların $\% 19,5^{\prime}$ inde mevcut idi ve psikiyatrik nedenlerden dolayı son altı ayda bir doktora başvuru oranı \%15,8 idi.

Sonuç: İntihar girişim metotlarından en yaygın olanı kendini zehirleme şeklinde idi. En belirgin risk grubu olarak genç ve evli ev hanımları görünmektedir. Bölgemizdeki intihar girişimi olaylarının epidemiyolojisi, Avrupa ve Doğu topluluklarında görülen intihar girişimlerinin bir karışımına benzemektedir.

Anahtar sözcükler: intihar girişimi, parasuisid, sosyodemografik özellikler, epidemiyoloji

Klinik Psikofarmakoloji Bulteni 2014;24(4):350-9

\section{ABSTRACT:}

Emergency room visits for suicide attempts: rates, trends and sociodemographic characteristics of suicide attempts in Northeastern Anatolia

Objective: In this study, we aimed to assess the epidemiology of suicide attempts, especially focusing on rates and trends in Northeastern Turkey.

Materials and Methods: This is a cross-sectional study including 893 parasuicide events recorded prospectively in 17 emergency rooms of state hospitals in two neighboring counties over three years. Information on each case was recorded on a standardized monitoring form that covered a series of sociodemographic and psychosocial features.

Results: In 2007, parasuicide rates per 100,000 inhabitants were 47.7 for females, 17.7 for males, and 32.5 for both genders. Suicide attempts were more common in women in all age groups except $\geq 50$ years. The most common methods of deliberate self-harm were as follows: medical drug/toxic substance ingestion (93.3\%), hanging (1.7\%), and cutting or stabbing (3.6\%). Housewives (53.8\%) formed the largest group among women. Physical domestic violence was a common reason for suicide attempts in women aged 15-34 years. The only cited reason for suicide attempts that was predominant in males was financial difficulties. A previous psychiatric diagnosis was present in $19.5 \%$ of parasuicide cases, and the rate of seeing a doctor for psychiatric reasons in the last 6 months prior to the suicide attempt was $15.8 \%$.

Conclusion: Self-poisoning is the most common method for attempted suicide. The risk groups in our region appeared to be younger and married females. The epidemiology of suicide attempt cases in our region resembles a mixture of both European and Asian communities' parasuicide patterns.

Keywords: suicide attempt, parasuicide, sociodemographic findings, epidemiology

Bulletin of Clinical Psychopharmacology 2014;24(4):350-9
'Assoc. Prof., Gulhane Military Medical Academy, Haydarpasa Training Hospital, Emergency Department, Istanbul - Turkey

${ }^{2}$ Assoc. Prof, Ataturk University, Faculty of Medicine, Emergency Department Erzurum - Turkey

${ }^{3}$ Assist. Prof, Ataturk University Faculty of Medicine, Department of Public Health, Erzurum - Turkey ${ }^{4}$ M.D., Fatih Family Health Center, Erzincan - Turkey

\section{Corresponding author:}

Assoc. Prof. Dr. Murat Eroglu, Gülhane Askeri Tıp Akademisi, Haydarpaşa Eğitim Hastanesi, Acil Tıp Anabilim Dalı, Üsküdar, İstanbul - Türkiye

\section{E-mail address:}

drmeroglu@yahoo.com

Date of submission:

November 14, 2012

Date of acceptance: February 08,2013

Declaration of interest: M.E, A.O.Y., M.U., A.S., H.A., M.N., M.E. The authors reported no conflict of interest related to this article. 


\section{INTRODUCTION}

Muslim countries have made relatively few contributions to studies about suicidality. This may be the result of a lack of available funding for suicide research or because little attention is paid to the suicide problem ${ }^{1}$. Another reason may be a lack of interest by researchers due to the generally held belief that attempted suicide is a rare event in Muslim countries ${ }^{2}$. Among females in Europe, the highest attempted suicide rate was found in the age group 15-24 years with values between 99 and 766 per 100,000 population. In male subjects of the same age group, these rates were lower, ranging between 66 and 372 per 100,000 ${ }^{3}$. In Iran, published attempted suicide rates per 100,000 population varied between 19.4 in 2005 and 16.3 in $2007^{4}$. In our country, suicide ranks tenth among the leading causes of death ${ }^{5}$. Official statistics in Turkey show that annually 3.33 per 100,000 population aged 15 years or over commit suicide $^{6}$.

Parasuicide is a "cry for help" behavior and an important predictor of potentially preventable intentional self-harm. Suicidal behavior constitutes a major public and mental health problem and is a significant drain on resources in both primary and secondary health care settings ${ }^{7}$. To date, only a small number of research studies have been done about people attempting suicide in Turkey. Yasan et al. have studied demographic characteristics of serious suicide attempts in southeastern Turkey ${ }^{8}$. Their aim was to elucidate causes of higher rates of suicide attempts in females compared to males. Similar to southeastern Turkey, there are more completed suicides among females than males in our region $^{9,10}$.

The present study aimed to present unselected 3-year epidemiological suicide attempt surveillance data of patients admitted to emergency rooms (ERs), and to identify sociodemographic and behavioral characteristics of non-fatal suicidal events from a catchment area in Northeastern Turkey. This is the most extensive study in its field conducted in Turkey thus far. Our multicenter study covers both urban and rural populations. We think that epidemiological characteristics and local factors contributing to parasuicides must be determined in order to find specific preventive interventions and to improve the monitoring and management of parasuicide patients.

\section{METHODS}

\section{Study Area}

Data were collected from two northeastern provinces of Turkey (Erzurum, Erzincan). Erzurum and Erzincan are counties which in 2007 had a total population of approximately $1,000,000$ (Erzincan 213,000, Erzurum 780,000) ${ }^{11}$. The economy of northeastern Turkey is based on animal husbandry and agriculture. Generally, multiple generations share the same household. The population is characterized by an aboveaverage level of education and income and a below-average level of unemployment and social problems compared to western Turkey. In the catchment area, $99 \%$ of the people are Muslims, and the gender distribution is $49.5 \%$ females and $50.5 \%$ males $^{11}$. By the year 2000 , the rate of urbanization in the northeastern part of Turkey was $57.3 \%$, the net migration rate was $-43.5 \%$, and the proportion of the population employed in agriculture and industry was $63 \%$ and $4 \%$, respectively ${ }^{12}$. Until now, a population-based prevalence study for depression has not been performed, nor have official suicide attempt rates been measured in eastern Turkey. In the East Anatolia region, the crude suicide rate (the number of suicides per 1,000 population in a given year) was 2.5 in 1998 and increased to 5.0 in $2006^{10}$.

\section{Definitions}

A suicide attempt was defined as 'An act with a non-fatal outcome, in which an individual deliberately initiates a non-habitual behavior that, without intervention from others, will cause selfharm, or deliberately ingests a substance in excess 
of the prescribed or generally recognized therapeutic dosage, and which is aimed at realizing changes which the subject desires via the actual or expected physical consequences' ${ }^{\prime 3}$. The individual should be aware that the act was a threat to his or her life in order for it to be considered a suicide attempt ${ }^{14}$. Violent attempts include those involving firearms, hanging, cutting, burning, jumping from heights, or using blunt instruments.

Self-poisoning is defined as the intentional self-administration of more than the prescribed dose of any drug, whether or not there is evidence that the act was intended to cause self-harm, and includes poisoning with non-ingestible substances and gas, overdoses of recreational drugs, and instances of severe alcohol intoxication which the clinical staff determines to be acts of self-harm ${ }^{15,16}$. Self-injury is defined as any injury recognized by clinical staff as having been intentionally (deliberately) self-inflicted ${ }^{15,16}$. In our study, we differentiated between rural and urban settings according to whether or not the respective population was at least 20,000 .

\section{Design}

In this cross-sectional study, a total of 893 parasuicide events were recorded in 17 ERs of state hospitals between January 1, 2006 and December 31, 2008 (three years). All Ministry of Health hospitals in the region participated in our study. In Erzurum, there were eight hospitals (two were urban); in Erzincan, there were nine hospitals (two were urban).

\section{Inclusion-Exclusion Criteria}

Patients admitted to emergency rooms with a "suicidal gesture" and those who had ingested lower doses of a toxic substance as a salient behavior to draw attention were also included. The recorded events include medically treated cases of parasuicide only; deliberate self-harm that was not brought to the attention of medical staff is not included. The exclusion criteria were accidental self-poisonings or injuries and inability to answer the questionnaire in the ER. People residing outside our regional borders who applied or transferred to the state hospitals in our region following suicide attempts were also excluded. Forty-five patients were excluded due to incomplete records.

\section{Data Collection}

Once an attempted suicide is suspected, information on each case has to be recorded and coded on a standardized monitoring form. The questionnaire covers a range of sociodemographic information (i.e., age, gender, employment, marital status, residence, educational level, and date and time of parasuicide), psychosocial features (method of attempted suicide, prior psychiatric treatment, previous suicide attempts/ history of deliberate self-harm, and any family history of suicide, etc.), and the prognosis of the patient (discharged, transferred, or hospitalized). In addition to interviewing the suicidal patient, collateral information was obtained from others who knew the patient, such as parents, relatives, or close friends, because the validity of reporting by the patient in interviews may be unreliable. Patients admitted to more than one institution after a suicide attempt were identified, and only one was recorded. The data were recorded either by the emergency staff or by the emergency physician responsible for the patient. These data were provided in hard copy logs, created through manual entry at the General Health Directorates of the two cities where continuous quality of data was ensured. Close cooperation with all medical services in the catchment area was sought in order to ensure the validity of the data. The data used here was related to cases of parasuicide (events), not persons. In other words, the same person can appear several times if he or she was involved in more than one parasuicidal act during the period of data collection. The data are based on one method per event (the method being considered most important) as Schmidtke et al. ${ }^{7}$ have previously reported. 


\section{Ethics and Statistical Analyses}

The study was approved by the Erzurum Local Ethics Committee (Date: 06, November, 2009; Decision No: 5). Prevalence of suicide attempts was calculated only for 2007, because 'general population rates' were available only for this year. Rates per 100,000 population (prevalence) were calculated using the population data of each catchment area in 2007. Pearson chi-square tests were used to test for the statistical significance of gender differences. Data were analyzed using the Statistical Package for the Social Sciences for Windows (version 11.5, SPSS, Chicago, IL). A 'p value $<0.05^{\prime}$ was considered statistically significant.

\section{RESULTS}

The total numbers of admissions to ERs because of suicide attempts between 2006 and 2008 were 312,325 , and 256, respectively. There was no significant difference in the annual distributions by gender between the annual data sets $(p>0.05)$. The number of male and female parasuicide admissions was similar in different seasons ( $\mathrm{p}>0.05)$.

In 2007, parasuicide rates per 100,000 inhabitants were 47.7 for females, 17.7 for males, and 32.5 for both genders (Table 1, Figure 1). The largest difference between male and female suicide attempts was in the age group of 15-24, where the ratio of females to males was $3.6: 1$. For both genders, the age group of 15-24 had higher rates than all other age groups. The lowest rates were recorded among those aged 50 and older for both sexes (Table 1, Figure 1). There was no significant difference between the prevalence of suicide attempts according to age groups and residential area $(\mathrm{p}>0.05)$.

Deliberate self-harm method types were as follows: medical drugs/toxic substance ingestion $(93.3 \%)$, hanging $(1.7 \%)$, cutting or stabbing (3.6\%), firearms $(0.3 \%)$, burning $(0.2 \%)$, jumping from high places $(0.6 \%)$, and other methods $(0.3 \%)$. Men used significantly more violent suicide methods than did women $(5.6 \%$ vs. $1.8 \%$; $\mathrm{p}<0.0001)$. Although violent suicide methods were used more in rural areas than in urban areas, the

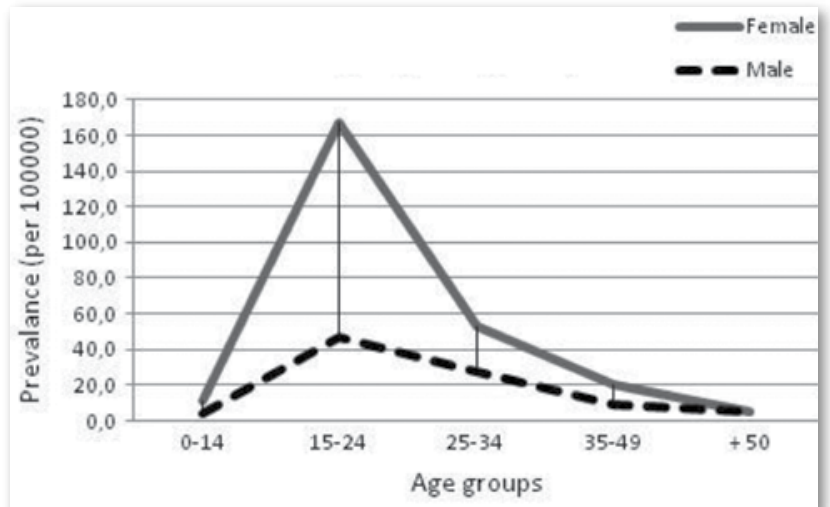

Figure 1: Prevalence of suicide attempts in Eastern Anatolia, by age groupsand gender, 2007

Table 1: Prevalence of suicide attempts in northeastern Anatolia, by age groups and gender, 2007

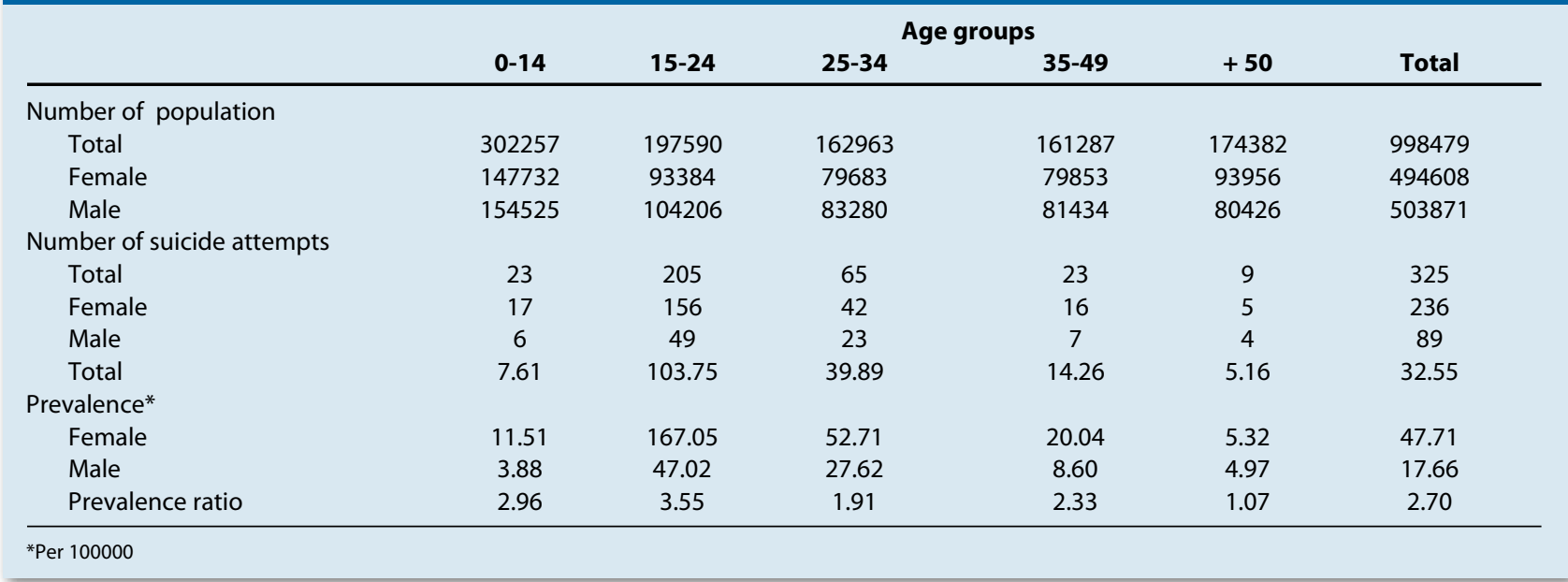




\begin{tabular}{|c|c|c|c|c|c|c|}
\hline \multirow[t]{2}{*}{ Characteristics } & \multicolumn{2}{|c|}{ Female } & \multicolumn{2}{|c|}{ Male } & \multirow[t]{2}{*}{ p value } & \multirow{2}{*}{$\begin{array}{l}\text { Total } \\
\text { n (\%) }\end{array}$} \\
\hline & $\mathbf{n}$ & $\%$ & $\mathbf{n}$ & $\%$ & & \\
\hline \multicolumn{7}{|l|}{ Parasuicide type } \\
\hline Violent & 12 & 1.8 & 13 & 5.7 & \multirow[t]{2}{*}{0.002} & $25(2.8)$ \\
\hline Nonviolent & 648 & 98.2 & 217 & 94.3 & & $865(97.2)$ \\
\hline \multicolumn{7}{|l|}{ Marital status } \\
\hline Married & 279 & 42.3 & 72 & 31.0 & \multirow[t]{5}{*}{0.006} & $351(39.3)$ \\
\hline Unmarried & 327 & 49.5 & 147 & 63.4 & & $474(53.1)$ \\
\hline Widowed & 6 & 0.9 & 3 & 1.3 & & $9(1)$ \\
\hline Divorced & 13 & 2.0 & 3 & 1.3 & & $16(1.8)$ \\
\hline Engaged & 35 & 5.3 & 7 & 3.0 & & $42(4.7)$ \\
\hline \multicolumn{7}{|l|}{ Residence } \\
\hline Rural & 263 & 43.7 & 94 & 43.3 & \multirow[t]{2}{*}{$n s^{*}$} & $357(43.6)$ \\
\hline Urban & 339 & 56.3 & 123 & 56.7 & & $462(56.4)$ \\
\hline \multicolumn{7}{|l|}{ Educational level } \\
\hline Uneducated & 61 & 9.3 & 14 & 6.0 & \multirow[t]{6}{*}{ ns } & $75(8.4)$ \\
\hline Literate & 41 & 6.2 & 8 & 3.4 & & $49(5.5)$ \\
\hline Elementary & 296 & 44.9 & 108 & 46.4 & & $404(45.3)$ \\
\hline High School & 167 & 25.3 & 76 & 32.6 & & $243(27.2)$ \\
\hline University & 59 & 9.0 & 18 & 7.7 & & 77(8.6) \\
\hline Unknown & 35 & 5.3 & 9 & 3.9 & & $44(4.9)$ \\
\hline \multicolumn{7}{|l|}{ Occupation } \\
\hline Employed & 44 & 7.1 & 72 & 34.6 & \multirow[t]{4}{*}{$<0.0001$} & $116(14)$ \\
\hline Unemployed & 396 & 63.7 & 68 & 32.7 & & $464(56)$ \\
\hline Student & 131 & 21.1 & 49 & 23.6 & & $180(21.7)$ \\
\hline Unknown & 50 & 8.1 & 19 & 9.1 & & $69(8.3)$ \\
\hline \multicolumn{7}{|c|}{ Previous parasuicide(s) } \\
\hline None & 527 & 88.1 & 177 & 83.5 & \multirow[t]{3}{*}{ ns } & $704(86.9)$ \\
\hline 1 & 61 & 10.2 & 31 & 14.6 & & $92(11.4)$ \\
\hline$\geq 2$ & 10 & 1.7 & 4 & 1.9 & & $14(1.7)$ \\
\hline \multicolumn{7}{|c|}{ Previous psychiatric diagnosis in the family } \\
\hline Yes & 10 & 2.2 & 5 & 3.1 & \multirow[t]{2}{*}{ ns } & $15(2.5)$ \\
\hline No & 440 & 97.8 & 155 & 96.9 & & $595(97.5)$ \\
\hline \multicolumn{7}{|c|}{ Previous parasuicides in the family } \\
\hline Yes & 15 & 3.0 & 4 & 2.2 & \multirow[t]{2}{*}{ ns } & $19(2.8)$ \\
\hline No & 492 & 97.0 & 177 & 97.8 & & $669(97.2)$ \\
\hline \multicolumn{7}{|c|}{ Previous psychiatric diagnosis in the patient } \\
\hline Yes & 103 & 19.6 & 35 & 19.1 & \multirow[t]{2}{*}{ ns } & $138(19.5)$ \\
\hline No & 423 & 80.4 & 148 & 80.9 & & $571(80.5)$ \\
\hline $\begin{array}{l}\text { Admission to a do } \\
\text { in last } 6 \text { months }\end{array}$ & & & & & & \\
\hline Yes & 95 & 16.1 & 33 & 15.1 & ns & $128(15.8)$ \\
\hline No & 494 & 83.9 & 186 & 84.9 & & $680(84.2)$ \\
\hline Prognosis & & & & & & \\
\hline Discharged & 365 & 55.3 & 105 & 45.1 & 0.01 & $470(66.5)$ \\
\hline Transferred & 215 & 32.6 & 85 & 36.5 & & 106(15) \\
\hline Hospitalized & 88 & 12.1 & 43 & 18.5 & & $131(18.5)$ \\
\hline
\end{tabular}

difference was not significant ( $\mathrm{p}>0.05)$.

According to current employment status, housewives $(53.8 \%)$ formed the largest group among women, while the employed (34.6\%) were the largest group among men. There was a significant difference between males and females in terms of suicide methods used, marital status, employment status, and hospitalization ratio (Table 2).

For females, familial problems (29.5\%), mental illness $(12.0 \%)$, and physical domestic violence $(8.9 \%)$ were the main declared reasons for deliberate self-harm (Table 3). For men, these were familial problems $(21.3 \%)$, problems with 


\begin{tabular}{|c|c|c|c|c|c|c|c|c|c|c|c|c|}
\hline \multirow[b]{3}{*}{ Reason } & \multicolumn{8}{|c|}{ Age groups } & \multirow{2}{*}{\multicolumn{2}{|c|}{+50}} & \multirow{2}{*}{\multicolumn{2}{|c|}{ Total }} \\
\hline & \multicolumn{2}{|c|}{$0-14$} & \multicolumn{2}{|c|}{$15-24$} & \multicolumn{2}{|c|}{$25-34$} & \multicolumn{2}{|c|}{$35-49$} & & & & \\
\hline & $\mathbf{F}(\%)$ & $M(\%)$ & $F(\%)$ & $M(\%)$ & $F(\%)$ & $M(\%)$ & $F(\%)$ & $M(\%)$ & $\mathbf{F}(\%)$ & $M(\%)$ & $\begin{array}{c}F(\%) \\
n=651\end{array}$ & $\begin{array}{c}M(\%) \\
n=230\end{array}$ \\
\hline Familial problems & $12(44.4)$ & $6(54.5)$ & $103(25.1)$ & $25(19.8)$ & $57(38.3)$ & $12(20.3)$ & $17(32.7)$ & $3(12.5)$ & $3(25.0)$ & $3(30.0)$ & $192(29.5)$ & $49(21.3)$ \\
\hline Physical Domestic & & & & & & & & & & & & \\
\hline Violence & $2(7.4)$ & $0(0.0)$ & $27(6.6)$ & $2(1.6)$ & $20(13.4)$ & $2(3.4)$ & $7(13.5)$ & $1(4.2)$ & $2(16.7)$ & $0(0.0)$ & $58(8.9)$ & $5(2.2)$ \\
\hline Fear of death & $0(0.0)$ & $0(0.0)$ & $16(3.9)$ & 684.8) & $1(0.7)$ & $2(3.4)$ & $3(5.8)$ & $1(4.2)$ & $0(0.0)$ & $0(0.0)$ & $20(3.1)$ & $9(3.9)$ \\
\hline Sexual harassment & $0(0.0)$ & $0(0.0)$ & $2(0.5)$ & $0(0.0)$ & $2(1.3)$ & $1(1.7)$ & $0(0.0)$ & $0(0.0)$ & $0(0.0)$ & $0(0.0)$ & $4(0.6)$ & $1(0.4)$ \\
\hline $\begin{array}{l}\text { Communication } \\
\text { problems }\end{array}$ & $1(3.7)$ & $0(0.0)$ & $28(6.8)$ & $4(3.2)$ & $4(2.7)$ & $6(10.2)$ & $3(5.8)$ & $3(12.5)$ & $0(0.0)$ & $1(10.0)$ & $36(5.5)$ & $14(6.1)$ \\
\hline $\begin{array}{l}\text { Problems with (sexual) } \\
\text { partner or intimate }\end{array}$ & & & & & & & & & & & & \\
\hline persons & $1(3.7)$ & $1(9.1)$ & $44(10.7)$ & $33(26.2)$ & $5(3.4)$ & $3(5.1)$ & $2(3.8)$ & $1(4.2)$ & $0(0.0)$ & $0(0.0)$ & $52(8.0)$ & $38(16.5)$ \\
\hline School problems & $2(7.4)$ & $0(0.0)$ & $22(5.4)$ & $4(3.2)$ & $0(0.0)$ & $1(1.7)$ & $0(0.0)$ & $0(0.0)$ & $0(0.0)$ & $0(0.0)$ & $24(3.7)$ & $5(2.2)$ \\
\hline Economic reasons & $0(0.0)$ & $0(0.0)$ & $3(0.7)$ & $7(5.6)$ & $9(6.0)$ & $11(18.6)$ & $3(5.8)$ & $5(20.8)$ & $0(0.0)$ & $1(10.0)$ & $15(2.3)$ & $24(10.4)$ \\
\hline Adolescence problems & $0(0.0)$ & $0(0.0)$ & $12(2.9)$ & $5(4.0)$ & $0(0.0)$ & $0(0.0)$ & $0(0.0)$ & $0(0.0)$ & $0(0.0)$ & $0(0.0)$ & $12(1.8)$ & $5(2.2)$ \\
\hline $\begin{array}{l}\text { Alcohol and drug } \\
\text { dependence }\end{array}$ & $0(0.0)$ & $0(0.0)$ & $2(0.5)$ & $1(0.8)$ & $0(0.0)$ & $0(0.0)$ & $0(0.0)$ & $0(0.0)$ & $0(0.0)$ & $0(0.0)$ & $2(0.3)$ & $1(0.4)$ \\
\hline Other illnesses & $0(0.0)$ & $0(0.0)$ & $22(5.4)$ & $4(3.2)$ & $8(5.4)$ & $0(0.0)$ & $1(1.9)$ & $0(0.0)$ & $0(0.0)$ & $1(10.0)$ & $31(4.8)$ & $5(2.2)$ \\
\hline Mental illness & $2(7.4)$ & $1(9.1)$ & $43(10.5)$ & $13(10.3)$ & $23(15.4)$ & 10(16.9) & $6(11.5)$ & $3(12.5)$ & $4(33.3)$ & $2(20.0)$ & $78(12.0)$ & $29(12.6)$ \\
\hline Unknown & $7(25.9)$ & $3(27.3)$ & $87(21.2)$ & $22(17.5)$ & $20(13.4)$ & $11(18.6)$ & $10(19.2)$ & $7(29.2)$ & $3(25.0)$ & $2(20.0)$ & $127(19.5)$ & $45(19.6)$ \\
\hline
\end{tabular}

(sexual) partner or intimate persons (16.5\%), and mental illness (12.0\%) (Table 3). Economic reasons, cited by males more than 25 years old, were the only reason given for suicide attempts for which male predominance was observed (Table 3 ). On the other hand, physical domestic violence was a common reason among female suicide attempters aged more than 25 years (Table 3 ). Of these women, $63.8 \%$ were married, $59.3 \%$ were housewives, and $50 \%$ were from rural areas.

\section{DISCUSSION}

The present study is the first large-scale prevalence study involving a comprehensive evaluation of parasuicide cases in Turkey. There have been three prevalence studies about parasuicides thus far in three different cities located in different regions of our country. The prevalence of suicide attempts reported for children and adolescents was $1.93 \%$ in Mersin (southern Turkey) ${ }^{17}$. The mean annual rate of suicide attempts per 100,000 was 47 for men and 113 for women in Ankara (central eastern Turkey) ${ }^{18}$ and 31.5 in Trabzon (northern Turkey) ${ }^{19}$. This difference may be due to cultural and economic differences among the different regions of Turkey. The socio-cultural structure of Eastern Turkey is similar to Middle-East countries, while cultural and economic indicators in Western Turkey resemble European standards. In Europe, the highest and lowest average male and female age-standardized rate of suicide attempts per 100,000 people were recorded in Helsinki (Finland: 314), Cergy-Pontoise (France: 462), and Guipuzcoa (Spain: 69), respectively ${ }^{20}$. Our results supported the observations of Steele et al., who pointed out that before puberty, the prevalence of suicidal behavior is rare; it increases steeply with age, peaking between the ages of 19 and 23 years $^{21}$. The highest mean parasuicide rates underscore the importance of developing risk-reducing strategies targeted at the younger part of the population $^{22}$. There are a few regions in which suicidal behavior shows almost identical figures for both genders, such as India, Singapore, Hong Kong, Kuwait, and Japan ${ }^{23,24}$; in a few parts of the world, like Sri Lanka and Helsinki (Finland), nonfatal suicidal acts are more common among men than women ${ }^{7,25}$. In brief, it is true to say that suicide attempts show differences between individuals from different cultural and religious backgrounds.

When our low prevalence of attempted suicide 
is compared with other countries, our results are compatible with the thesis suggested by Steele et al. ${ }^{21}$ that any religious observance seems to be protective and on the other hand, suicide attempts may be hidden by individuals. For example, while examining the mortality data of 17 predominantly Islamic countries and the United Kingdom, Pritchard and Amanullah found that suicide rates were lower in most of these Islamic countries in comparison with the United Kingdom ${ }^{26}$. In more Catholic regions, suicide rates are mostly lower and the rate of undetermined causes of death is higher. In some Catholic regions and also in Islam, suicide victims are not buried with religious ceremonies $^{27}$, therefore increasing the probability of hiding suicide. On the other hand, suicide rates are higher in more Protestant regions. Schmidtke describes this situation as resulting from differences in religious responses to suicide ${ }^{20}$.

The majority of suicide attempters were young married or single housewives with low levels of education, and drug overdose was the most common method of suicide attempt in our research, as it had been in previous samples in Turkey ${ }^{28-30}$. We observed that the total unemployment rate (56\%) was far higher than the regional unemployment rate $(9.9 \%)$. Similarly, in European studies suicide attempts were seen in social categories associated with social destabilization and poverty?

It is a fact that the prevention, recognition, and effective treatment of mental disorders will continue to play a key role in suicide prevention ${ }^{31}$. In our region, previous psychiatric diagnosis was present in $19.5 \%$ of parasuicide cases and the rate of seeing a doctor for psychiatric reasons in the 6 months prior to the suicide attempt was $15.8 \%$. Altindag et al. found in southeastern Turkey that only $15 \%$ of suicide victims with psychiatric disorders received treatment in their city9. They attributed this result to the fact that the concept of "mental illness" in eastern Turkey was still largely restricted to persons with severely disturbed thinking or behavior. In another study in our region, we found that $81 \%$ of parasuicide cases had not been admitted to any psychiatric polyclinic in a state hospital before the suicide attempt or after having been discharged from the hospital. The rate of those who attempted to enter the psychiatric polyclinic before and after the suicide attempt was $4 \%$ and $11.5 \%$, respectively ${ }^{32}$. A British study observed that nearly half of older adults who committed suicide had visited their general practitioner in the month before their deaths, although more than $50 \%$ of these visits were for physical complaints ${ }^{33}$. In Norway, almost $80 \%$ of suicide attempters reported previous support from health and social services for mental or social problems, and significantly more females than males reported previous contact with psychiatric care ${ }^{22}$. These results show that requests for psychiatric help were relatively low in our region compared to previously mentioned studies. In our region, families attempt to manage personal and interpersonal difficulties as well as serious psychiatric problems internally within the family.

In the USA, one third of attempted suicide visits resulted in direct hospitalization, one third of the patients were transferred to another facility, and none died while in the $\mathrm{ER}^{34}$. Our transfer and hospitalization rates were $15 \%$ and $18.5 \%$, respectively, and hospitalization of males was significantly more common than of females. Johnson and colleagues have explained this, writing that 'the female gender role comprises rights within family life and responsibilities that protect women from engaging in "successful" suicidal behavior; therefore they use less lethal suicide methods ${ }^{35}$.

In the present study, the reasons for suicide attempts by youths were similar to those in other parts of the world. Parent-child conflicts, school problems, challenges resulting from emotional relations with friends, and peer conflicts played major roles as the precipitating factors for children under 16 years of age ${ }^{21}$. Sayar et al. reported in their study on adolescent suicide attempts that nearly half of the subjects mentioned familial problems as the trigger for suicide attempts ${ }^{36}$. In our study, patients from the 15-24 age group, who constitute the majority of 
cases, specified the most common suicide reasons as family problems, domestic violence, communication problems, problems with (sexual) partner or intimate persons, developmental period problems, and school problems (pressure in school and school failures) (Table 3). In our study, female subjects experienced more family conflicts compared to males. We think the roots of the reason why females experienced more family conflicts compared to males lie in our eastern family characteristics. Most marriages in northeastern Turkey are arranged by parents, and women generally have little or no say in the selection of their partners. On the other hand, the greater presence of married women in our research means that they may have had difficulties with their husbands, as Khan et al. has described well ${ }^{4}$.

Domestic violence against women is a serious public health concern because of its negative and harmful impact on the mental, physical, and social health of women. According to data from the Institution of Family Research, 35\% of women in Turkey have experienced physical violence from their husbands. Domestic violence was common to all socioeconomic levels, both in urban and rural areas ${ }^{37}$. A study including married women treated in the psychiatric outpatient clinic of a university hospital showed that physical domestic violence against women in the 16-29 age group was highly prevalent (57\%) and that women were trying to hide it. The prevalence of emotional violence was $36 \%$, economic $32 \%$, sexual $31 \%$, and verbal $29 \%^{38}$. Our study is important because it demonstrates that physical domestic violence is an important reason for suicide attempts in our region, especially for females more than 25 years old.

People who engaged in suicidal behavior reported significantly lower employment rates and earnings ${ }^{39}$. In our sample, financial difficulty was the only 'stated suicide reason' in which men were more prevalent. In southeastern Turkey, Yasan et al. also found that the rate of economic problems was significantly higher in males than in females ${ }^{8}$. It is known that economic stressors and poverty increase the propensity towards suicide through association with suicidogenic conditions, including unemployment, financial stress, family instability, and mental troubles ${ }^{40,41}$.

Sexual harassment has rarely been identified by the patients as a cause of suicide attempts. We think that for a woman who depends on her family socially and financially, it is not possible to endanger her relationship by disclosing abuse, especially if the perpetrator is a relative. For that reason, it may be reasonable for women not to identify the true cause of the suicide attempt in the case of "sexual harassment".

\section{Limitations}

The report is exclusively based on the patients' self-reports. Self-reported suicide attempts have limited validity and are liable to misreporting. It can be difficult to analyze "atypical" intentional suicide attempts such as motor vehicle crashes, gunshot victims, cases of jumping from high places, or patients with similar traumas, especially if the patients are unconscious. Thus, this may affect our proportionally low violent suicide attempt rate. The results cannot be generalized to the overall population of those who attempt suicide.

According to the Turkish Statistical Institute, the "northeastern region of Turkey" consists of 7 counties. We used the name of this region in the title, but the study was conducted only in the two biggest counties of this region.

\section{CONCLUSION}

Due to its geographical location, Turkey has long been the bridge between Europe and the East, between the Christian and Muslim worlds. As a result, the epidemiology of suicide attempt cases in our region resembles a mixture of both European and Asian communities' parasuicide characteristics. The risk groups in our region appeared to be younger and married females. Conflict within the family was the most frequent psychological stress factor. Physical domestic 
violence was a common reason among women more than 25 years old who attempted suicide. The study highlights the need for culture-specific, emotion-focused, problem-focused, and expert healing systems research on suicidal behavior in northeastern Turkey.

\section{References:}

1. Cardinal C. Three decades of suicide and life-threatining behavior: A bibliometric study. Suicide Life Threat Behav 2008;38(3):260-73. [CrossRef]

2. Khan MM, Hyder AA. Suicides in the developing world: case study from Pakistan. Suicide Life Threat Behav 2006;36(1):7681. [CrossRef]

3. Hawton K, Arensman E, Wasserman D, Hulten A, Bille-Brahe $\mathrm{U}$, Bjerke $\mathrm{T}$, et al. Relation between attempted suicide and suicide rates among young people in Europe. J Epidemiol Community Health 1998;52(3):191-4. [CrossRef]

4. Saberi-Zafaghandi MB, Hajebi A, Eskandarieh S, AhmadzadAsl M. Epidemiology of suicide and attempted suicide derived from the health system database in the Islamic Republic of Iran: 2001-2007. East Mediterr Health J 2012;18(8):836-41.

5. Statistics, S.I.o., Suicide Statistics. Ankara: State Institute of Statistics Press, 2002.

6. Sayil I. Review of suicide studies in Turkey. Crisis 1997;18(3):124-7. [CrossRef]

7. Schmidtke A, Bille-Brahe U, De Leo D, Kerkhof A, Bjerke T, Crepet $\mathrm{P}$ et al. Attempted suicide in Europe: rates, trends and sociodemographic characteristics of suicide attempters during the period 1989-1992. Results of the WHO/EURO Multicentre Study on Parasuicide. Acta Psychiatr Scand 1996;93(5):327-38. [CrossRef]

8. Yasan A, Danis R, Tamam L, Ozmen S, Ozkan M. Sociocultural features and sex profile of the individuals with serious suicide attempts in southeastern Turkey: a one-year survey. Suicide Life Threat Behav 2008;38(4):467-80. [CrossRef]

9. Altindag A, Ozkan M, Oto R. Suicide in Batman, Southeastern Turkey. Suicide Life Threat Behav 2005;35(4):478-82. [CrossRef]

10. Suicide Statistics 2006, T.S. Institute, Editor, Turkish Statistical Institute, Printing Division, Ankara: Ankara 2006. (Turkish)

11. Institute., T.T.S., http://tuikapp.tuik.gov.tr/adnksdagitapp/ adnks.zul.

12. Regional Indicators 2006, T.C.B.T.İ. Authority, Editor, Turkey Statistical Institute Publications, Ankara, Turkey: Ankara. 2007. (Turkish)

13. Christiansen E, Jensen BF. Risk of repetition of suicide attempt, suicide or all deaths after an episode of attempted suicide: a register-based survival analysis. Australian and New Zealand Journal of Psychiatry 2007;41(3):257-65. [CrossRef]

\section{Acknowledgements}

The authors extend special thanks to Assoc. Prof. Dr. Serhat Vancelik and Dr. Mesut Turan, the provincial health directors of Erzurum and Erzincan, respectively.

14. Asberg M, Träskman L, Thoren P. 5-HIAA in the cerebrospinal fluid. A biochemical suicide predictor? Arch Gen Psychiatry 1976;33(10):1193-7. [CrossRef]

15. Harriss L, Hawton K, Zahl D. Value of measuring suicidal intent in the assessment of people attending hospital following self-poisoning or self-injury. $\mathrm{Br} \mathrm{J}$ Psychiatry 2005;186:60-6. [CrossRef]

16. Hawton K, Fagg J, Simkin S, Bale E, Bond A. Trends in deliberate self-harm in Oxford, 1985-1995. Implications for clinical services and the prevention of suicide. $\mathrm{Br} \mathrm{J}$ Psychiatry 1997;171:556-60. [CrossRef]

17. Toros F, Bilgin NG, Sasmaz T, Bugdayci R, Camdeviren H. Suicide attempts and risk factors among children and adolescents. Yonsei Med J 2004;45(3):367-74. [CrossRef]

18. Devrimci-Ozguven H, Sayil I. Suicide attempts in Turkey: results of the WHO-EURO Multicentre Study on Suicidal Behaviour. Can J Psychiatry 2003;48(5):324-9.

19. Bilici M, Bekaroglu M, Hocaoglu C, Gurpinar S, Soylu C, Uluutku N. Incidence of completed and attempted suicide in Trabzon, Turkey. Crisis 2002;23(1):3-10. [CrossRef]

20. Schmidtke A. Perspective: suicide in Europe. Suicide Life Threat Behav 1997;27(1):127-36.

21. Steele MM, Doey T. Suicidal Behaviour in Children and Adolescents. Part 1: Etiology and Risk Factors. Can J Psychiatry 2007;52(6 Suppl 1):21S-33S.

22. Dieserud G, Loeb M, Ekeberg O. Suicidal behavior in the municipality of Baerum, Norway: a 12-year prospective study of parasuicide and suicide. Suicide Life Threat Behav 2000;30(1):61-73.

23. Stefanello S, Cais CF, Mauro ML, Freitas GV, Botega NJ. Gender differences in suicide attempts: preliminary results of the multisite intervention study on suicidal behavior (SUPRE-MISS) from Campinas, Brazil. Rev Bras Psiquiatr 2008;30(2):139-43. [CrossRef]

24. Cheng ATA, Lee CS. Suicide in Asia and the Far East, in Suicide and Attempted Suicide, H.K. Hawton K, Editor. 2000, John Wiley \& Sons: Chichester. p.29-48. [CrossRef]

25. Marecek J. Culture, gender, and suicidal behavior in Sri Lanka. Suicide Life Threat Behav 1998;28(1):69-81.

26. Pritchard C, Amanullah S. An analysis of suicide and undetermined deaths in 17 predominantly Islamic countries contrasted with the UK. Psychological Medicine, 2007; 37(3):421-30. [CrossRef] 
27. T.C. Diyanet Isleri Baskanlıgı http://www.diyanet.gov.tr/ yayin/basiliyayin/ydinikavramlaryazdir.asp?id=874. Update January 2013.

28. Ozdel O, Varma G, Atesci FC, Oguzhanoglu NK, Karadag F, Amuk T. Characteristics of suicidal behavior in a Turkish sample. Crisis 2009;30(2):90-3. [CrossRef]

29. Tuzun B, Polat O, Vatansever S, Elmas I. Questioning the psycho-socio-cultural factors that contribute to the cases of suicide attempts: an investigation. Forensic Sci Int 2000;113(1-3):297-301. [CrossRef]

30. Sayar K, Acar B. Risk factors in suicide attempts victims with the use of psychotropic drugs. Klinik Psikofarmakoloji Bulteni-Bulletin of Clinical Psychopharmacology 1999;9(4):208-12. (Turkish)

31. Foster T, Gillespie K, McClelland R, Patterson C. Risk factors for suicide independent of DSM-III-R Axis I disorder. Casecontrol psychological autopsy study in Northern Ireland. Br J Psychiatry 1999;175:175-9. [CrossRef]

32. Emet M, Beyhun N, Uzkeser M, Cakir Z, Aslan S. Main Differences In Childhood And Adult Oral Exposures. Bratisl Lek Listy 2011;112(6):346-52.

33. Harwood DM, Hawton K, Hope T, Jacoby R. Suicide in older people: mode of death, demographic factors, and medical contact before death. Int J Geriatr Psychiatry 2000;15(8):73643. [CrossRef]
34. Doshi A, Boudreaux ED, Wang N, Pelletier AJ, Camargo CA Jr. National study of US emergency department visits for attempted suicide and self-inflicted injury, 1997-2001. Ann Emerg Med 2005;46(4):369-75. [CrossRef]

35. Johnson GR, Krug EG, Potter LB. Suicide among adolescents and young adults: a cross-national comparison of 34 countries. Suicide Life Threat Behav 2000;30(1):74-82.

36. Sayar K, Ozturk M, Acar B. Psychological Factors in Adolescent Drug Overdosers. Klinik Psikofarmakoloji Bulteni-Bulletin of Clinical Psychopharmacology 2000; 10(3):133-8.

37. Kocacik F, Dogan O, Domestic violence against women in Sivas, Turkey: survey study. Croat Med J 2006; 47(5):742-9.

38. Akyuz A, Kugu N, Dogan O, Ozdemir L. Domestic violence, marriage problems, referral complaints and psychiatric diagnosis of the married women admitted to a psychiatry outpatient clinic. New Symposium 2002;40(2):41-8. (Turkish)

39. Kalist DE, Molinari NA, Siahaan F. Income, employment and suicidal behavior. J Ment Health Policy Econ 2007;10(4):17787.

40. Stack S. Suicide: a 15-year review of the sociological literature. Part I: cultural and economic factors. Suicide Life Threat Behav 2000;30(2):145-62.

41. Rich CL, Warstadt GM, Nemiroff RA, Fowler RC, Young D. Suicide, stressors, and the life cycle. Am J Psychiatry 1991;148(4):524-7. 